\title{
Television Advertisements Motivating Western lifestyle on 'College Youth'
}

\section{Kavitha $\mathbf{V}^{*}$}

Department of Journalism and Mass Communication, Vivekananda College, Agastheeswaram, Tamil Nadu, India

\begin{abstract}
Television advertisements being announcers have their own appeal in gaining the young audience attention. Western world has its significant influence in India in the avenues of fashion, trend, consuming products and on the wholesome lifestyle. While television advertisements promote the sales of products and services, western product advertisements give the audience an idea of 'how much' the usual living can be westernized. College students take keen notice of trend and fashion; they constantly try to be updated. This study was to find out 'to what extent' television advertisements motivate western lifestyle among college youth. Accordingly, Quantitative Survey method was adopted for the study. The universe of research was college students from three different cities Nagercoil, Tirunelveli and Madurai of age group ' 17 to 23'. The size of the sample was 600 ; and Non-probabilistic sampling method was employed. The 'instrument' for gathering data was a simplified and focused questionnaire containing thirty two questions. The summary outcome from the questionnaire portrayed that the result indicates 'College youth gets influenced by television advertisements in adapting western lifestyle'. The study concludes Western product advertisements encourage the students to try new brands and shift to Western brands. Students buy Western products because of Prestige, Price, Peer pressure, Brand identity, Endorsement, Attractive ad, Organic, Reliable and Ideal. Students regret Lack of money for not buying a Western product. Being modern and westernized was admired by the college youths; thereby creating a psychological imprint reflecting in their outlook.
\end{abstract}

Keywords: Television advertisement; Westernization; Lifestyle; College youth; Western brands

\section{Introduction}

Advertisements announce the existence of a product to the target audience through mass media like print, radio, television and networking sites. It is a form of marketing communication used to persuade an audience to take or continue some action, usually with respect to a commercial offering. The origin comes from Latin; wherein 'ad vertere' means "to turn toward". It is the action of making generally known; a calling to the attention of public [1].

Television advertisements promote western lifestyle by promoting products along with the western culture so attractively that the Indian youth are encouraged to follow western lifestyle as they see in the television advertisement. Western culture has considerably affected almost every dimension of the society. Television advertisements exhibit life style and apparent characteristics of the society. Each and everything including clothing, fashion, food, media, communication and traditions has been tremendously affected by the advent of western culture [2]. As globalization has touched heights of enlightening world's different cultures, western culture being the most influencing has set foot among the college youth through media. Advertisements being subtle invaders of consciousness are influencing tool where anything and everything can be announced and the audience act passively while buying products.

Lifestyle is the population's choice of recreation, clothing, and mode of transportation, communication and consumption of goods. Advertising and marketing practitioners are continually and constantly trying to find the 'best suitable way' to communicate with people when advertising is intended to crosses national boundaries and increasing the extent of reach. Especially western countries make it a 'normalized standard' for youngsters to be trendy and fit. Fashion and style always had top spot for western branded products. Brand identity compels the youth to be a user of that brand [3].
Fair skin, attractive body shape, western fashion, western interiors, western food, western houses, western consumer goods, etc. are the predilection and interest of the Indian youth that media especially TV advertisements pose on them. Due to globalization western television channels are commonly seen at every Indian houses. Television advertisements instantly inform the college youth about a variety of products available in the market such as regional, national and international. The significance of the study was to investigate the role of television advertisements in captivating the college youth towards western life style [4].

\section{Theoretical Framework}

The Theoretical background for this study was Social Learning Theory, coined by Albert Bandura posits that individuals develop general behavior and attitudes by modeling the behavior of others. Individuals learn or model behavior, values, attitudes, and skills through the observation of other individuals, or through observations of electronic or print media. This coincides with the effect of mass media on its audience, not only confined to the behavior of others in the vicinity. The theory suggests that a lot of learning takes place through observation first, prior to doing it personally [5].

According to social learning theory, Youth learn from the television

${ }^{*}$ Corresponding author: Kavitha V, Assistant Professor, Department of Journalism and Mass Communication, Vivekananda College, Agastheeswaram-629701, Tamil Nadu, India, Tel: +91 7502650 699; E-mail: mailatkv45@gmail.com

Received July 29, 2017; Accepted September 20, 2017; Published September 25, 2017

Citation: Kavitha V (2017) Television Advertisements Motivating Western lifestyle on 'College Youth'. J Mass Communicat Journalism 7: 347. doi: 10.4172/21657912.1000347

Copyright: ( 2017 Kavitha V. This is an open-access article distributed under the terms of the Creative Commons Attribution License, which permits unrestricted use, distribution, and reproduction in any medium, provided the original author and source are credited. 
advertisements that demonstrate a product. Endorsement by favorite actors attracts the youths. Young college students tend to follow the modeling by the actors and buy products in the idea of becoming like them. Trends on the dressing and fashion, transportation and communication, food and health, beauty and fitness are also taken from television advertisements and followed by the college youths.

\section{Methodology}

Whilst reviewing numerous journal publications and research study projects, it has been observed that quantitative survey method was the most prevalent, result oriented, effective and constructively efficient mode of study. Based on the aforesaid reachable study method similar pattern is followed. The study was conducted among college students of age 17 to 23 . The data have been collected from 6 colleges in three different cities - Nagercoil, Tirunelveli and Madurai. Nonprobabilistic sampling technique was used. The sample size of this study was 600 . Amongst the 600 respondents 300 were male and 300 female. A simple and focal questionnaire was constructed for the purpose of data gathering on a scale of 1 to 5 .

\section{Analysis and discussion}

Based on the analysis of quantitative survey, following data show the frequency of westernization of college youth through the surveillance of Television Advertisements.

\section{Television advertisement}

As an outcome, $39.5 \%$ of the students sometimes and $28 \%$ students often came across TV advertisements. Out of 600 respondents, $38.5 \%$ students like watching television advertisements to some extent and $25 \%$ students like watching television advertisements. Also, $70.9 \%$ of students are eager to 'watches, costumes, accessories, perfume/body spray and footwear' advertisements (Table 1).

\section{Urge to purchase products}

In a nutshell, $34.8 \%$ students have the urge to purchase the advertised products to a normal extent, 62 students have urge to purchase the advertised product to a great extent and 48 have no desire to purchase the advertised products. Also, 133 students have often purchased products after watching TV advertisements, 52 students have very often purchase and 63 students never purchased products after watching TV advertisements (Table 2).

\section{Shifts to western brands}

As an outcome, $36.7 \%$ students agree that models encourage purchase of the advertised products, $13.2 \%$ students strongly agree and 39 strongly disagree. Also, 27.3\% students often shift to western products, 130 students rarely, 50 students very often and 46 students never shift to western products (Table 3 ).

\begin{tabular}{|c|c|c|c|c|c|}
\hline \multicolumn{3}{|c|}{ Come across TV ad } & \multicolumn{3}{c|}{ Like watching TV ad } \\
\hline & Frequency & Percent & & Frequency & Percent \\
\hline Never & 30 & 5.0 & Not at all & 62 & 10.3 \\
\hline Rarely & 87 & 14.5 & Little & 117 & 19.5 \\
\hline Sometimes & 237 & 39.5 & Somewhat & 231 & 38.5 \\
\hline Often & 168 & 28.0 & Much & 150 & 25.0 \\
\hline Very often & 78 & 13.0 & Very much & 40 & 6.7 \\
\hline Total & 600 & 100.0 & Total & 600 & 100.0 \\
\hline
\end{tabular}

Table 1: College youth come across TV Ad and like watching TV Ad.

\begin{tabular}{|c|c|c|c|c|c|}
\hline \multicolumn{3}{|c|}{ Urge to try a new brand } & \multicolumn{3}{c|}{ Purchase advertised product } \\
\hline & Frequency & Percent & & Frequency & Percent \\
\hline Not at all & 48 & 8.0 & Never & 63 & 10.5 \\
\hline Little & 105 & 17.5 & Rarely & 129 & 21.5 \\
\hline Somewhat & 209 & 34.8 & Sometimes & 223 & 37.2 \\
\hline Much & 176 & 29.3 & Often & 133 & 22.2 \\
\hline Very much & 62 & 10.3 & Very often & 52 & 8.7 \\
\hline Total & 600 & 100.0 & Total & 600 & 100.0 \\
\hline
\end{tabular}

Table 2: Urge to purchase advertised products and try new brands by college youth.

\begin{tabular}{|c|c|c|c|c|c|}
\hline \multicolumn{3}{|c|}{ Models encourage purchase } & \multicolumn{3}{c|}{ Shift to western brands } \\
\hline & Frequency & Percent & & Frequency & Percent \\
\hline Strongly Disagree & 39 & 6.5 & Never & 46 & 7.7 \\
\hline Disagree & 51 & 8.5 & Rarely & 130 & 21.7 \\
\hline $\begin{array}{c}\text { More or less } \\
\text { Agree }\end{array}$ & 211 & 35.2 & Sometimes & 210 & 35.0 \\
\hline Agree & 220 & 36.7 & Often & 164 & 27.3 \\
\hline Strongly agree & 79 & 13.2 & Very often & 50 & 8.3 \\
\hline Total & 600 & 100.0 & Total & 600 & 100.0 \\
\hline
\end{tabular}

Table 3: Models encourage College youth to purchase and shift to western brands

\section{Buy western products}

In a nut-shell, $34.2 \%$ students buy western products for prestige sometimes, $22.7 \%$ often buy, 77 students never and 52 very often buy Western products for prestige. Also, 44 students always buy western products because of peer pressure, $26.2 \%$ students often and 89 students never buy western products because of peer pressure. Furthermore, $36.2 \%$ students often, 119 students very often and 23 students never buy western products because of brand identity (Table 4 ).

The results portray $25.7 \%$ students frequently buy western products because of endorsement, 85 students never and 61 students buy western products very often because of endorsement. Also, 32\% students often buy western products because of attractive ads, 79 students very often and 57 students never. Further, 28.2\% students often buy western products since they are reliable, 73 students very often and 43 never buy western products since they are reliable.

The finding says $31.5 \%$ often buy western products as they are ideal, 86 very often, 82 rare and 31 never buy Western products as they are ideal. 162 students often buy Western products since they promote status among friends, 72 students never and 77 students very often buy western products since they promote status among friends.

\section{Lack of money}

As an outcome, $25.7 \%$ students often regretted that lack of money was the only reason for not buying a foreign product, 81 students rarely regret and 67 students very often regret. 125 students often envied their friends with foreign branded product that they did not have money to buy, 120 students never envied and 59 students very often envied. Also, $27 \%$ students often felt that owning a foreign brand increases status among their friends, 99 students felt very often and 89 students never felt that owning a foreign brand increases status among their friends (Table 5).

From the analysis, the study states that International brand advertisements considerably encourage the students to buy new brands. The more the students have the urge to try new brands, the more they tend to shift to Western brands. The more the students shift to Western brands the more they like watching TV ads seeking inspiration. Shifting brands need idea about which brand is more advantageous 
Citation: Kavitha V (2017) Television Advertisements Motivating Western lifestyle on 'College Youth'. J Mass Communicat Journalism 7: 347 . doi: 10.4172/2165-7912.1000347

Page 3 of 3

\begin{tabular}{|c|c|c|c|c|c|c|c|c|}
\hline \multicolumn{3}{|c|}{ Prestige } & \multicolumn{3}{|c|}{ Attractive Ad } & \multicolumn{3}{|c|}{ Promote status among friends } \\
\hline & Frequency & Percent & & Frequency & Percent & & Frequency & Percent \\
\hline Never & 75 & 12.5 & Never & 57 & 9.5 & Never & 72 & 12.0 \\
\hline Rarely & 132 & 22.0 & Rarely & 94 & 15.7 & Rarely & 85 & 14.2 \\
\hline Sometimes & 205 & 34.2 & Sometimes & 178 & 29.7 & Sometimes & 204 & 34.0 \\
\hline Often & 136 & 22.7 & Often & 192 & 32.0 & Often & 162 & 27.0 \\
\hline Very often & 52 & 8.7 & Very often & 79 & 13.2 & Very often & 77 & 12.8 \\
\hline Total & 600 & 100.0 & Total & 600 & 100.0 & Total & 600 & 100.0 \\
\hline
\end{tabular}

Table 4: College youth buy western products because of Prestige, Attractive Ads and to promote status among friends.

\begin{tabular}{|c|c|c|c|c|c|}
\hline \multicolumn{3}{|c|}{ Lack of money } & \multicolumn{3}{c|}{ Owning increases status } \\
\hline & Frequency & Percent & & Frequency & Percent \\
\hline Never & 74 & 12.3 & Never & 89 & 14.8 \\
\hline Rarely & 81 & 13.5 & Rarely & 79 & 13.2 \\
\hline Sometimes & 224 & 37.3 & Sometimes & 171 & 28.5 \\
\hline Often & 154 & 25.7 & Often & 162 & 27.0 \\
\hline Very often & 67 & 11.2 & Very often & 99 & 16.5 \\
\hline Total & 600 & 100.0 & Total & 600 & 100.0 \\
\hline
\end{tabular}

Table 5: Owing western brands increase status among friends and percentage of students regret lack of money.

to buy. Students who prefer western clothing, also prefers Western style products according to the outfits they wear. Students who came across TV advertisements very often seem to purchase products after watching TV advertisement more when compared to those who came across sometimes and never. Students get persuaded by television advertisement, because of which they very often buy products. Favorite actors influence a lot in the buying of Western products. Students take pride in buying Western products creating a feel-factor of 'beyond the horizon'. Students believe that price of Western products are reasonable. They buy Western products as friends buy and use them; due to psychological factor probing to be at par with peer-group. Students buy certain Western brands because of brand identity. Attractive advertisements were also a reason for the students to buy western products. Reliability of Western products is well presented in television advertisements thereby imprinting long-lasting 'constructive image' in the minds of the students. Television advertisements make Western products ideal to be bought by the youngsters. Western products being costlier than Indian products, when the students cannot afford it they tend to regret the lack of money.

Television advertisements communicate about the existence of new brands of consumer products. College youth being audience to the television programs watch those advertisements and get informed about the products. International brands play a great role in westernizing the college youth by constantly announcing that usage of Western products gives higher status and recognition among friends. Advertising agencies fabricate the 'selling messages' in such a way that the target audience being youth when they watch such programs get to be exposed to the advertisements; and the outcome remains intact in them. Scenes in the advertisements attract the youth to adapt the Western lifestyle due to the 'lasting-impact' in the fascinating environ portrayed. When television programs get sponsored by international consumer product companies they obviously keep showing their advertisements which trigger the audience, and persuade them to buy those products.

\section{Conclusion}

In light of all the afore-said analysis and observation, I conclude that the college youth shift to western brands after the surveillance of television advertisements. According to the youth, western lifestyle is

more attractive, an eye-candy, tech-savy, comfy and trendy to follow. College youths prefer Western Clothing and styling products, Health and fitness products, Food and byproducts, Communication tools and Transportation modes. They tend to discover from the television advertisements about the various available products and choose the most attractively presented products if affordable. International brand advertisements encourage the students to buy new brands and shift to Western brand products. Lack of insufficient money was regretted by the college youth for not being able to buy a Western product. Western companies make sure that they attract the young India through splashy, word-catchy stylish advertisements by portraying Western culture and make them follow the Western lifestyle.

Hence, in a nut-shell western advertisements tend to create a 'lasting image' in College youth vide 5 key elements: (1) Constructive play with feel and psychology of Youth, (2) Tailoring Youth/ Students need, (3) Instigate the urge to Purchase in Youth, (4) Sustaining the purchasing power of Youth, (5) Reforming the 'fashion of consumption' of Youth.

\section{References}

1. Moschis G P, Mitchell LG (1986) Television Advertising and Interpersonal Influences on Teenagers Participation in Family Consumer Decisions. Advances in Consumer Research 13: 181-186.

2. Kaur H, Kaur R (2002) Fashion Awareness among Rural and Urban Adolescents. Journal of Social Research 43: 37-40.

3. Gabriel S (2006) The Impact of Television Advertisements on Youth: A Study The IUP Journal of Marketing Management

4. Gupta DK (2007) Impact of Celebrity Endorsement on Consumer Buying Behaviour and Brand Building, Social Science Research Network.

5. Kotwal N, Gupta N, Devi A (2008) Impact of T.V Advertisements on Buying Pattern of Adolescent Girls. Journal of Social Sciences 16: 51-55. 